\title{
Hiijrah: Islamic E-Commerce Disurpted Strategy
}

\author{
M. Ruslianor Maika
}

Universitas Muhammadiyah Sidoarjo

email:mr.maika@umsida.ac.id

\section{Irwan Alnarus Kautsar}

Universitas Muhammadiyah Sidoarjo

email: irwan@umsida.ac.id

\begin{abstract}
The aims of this research is to find an Islamic eCommerce disrupted strategy using $5 \mathrm{C}$ model. Our methodologies is a qualitative descriptive to evaluate and describe aspects of innovation based on $5 \mathrm{C}$ model. We propose a systematic approach to identify disruptive strategies of Prophet Muhammad displacing the big incumbent market and also provide commercialize the strategy for developing and implementing Islamic Commerce to be electronics. Hijrah is the best disruptive approach that was proven by Prophet Muhammad (PBUH) with the closing of the Bani Qainuqa market. He implemented 4C model commerce, collaboration, communication, connection, and only computation that He can't. The state art of this research are the customers not only 'go shopping', but literally are shopping. While the sellers not only 'go selling' but Hijrah with the great intention. It is not only about adopting technology but also as a disrupted strategy.
\end{abstract}

Keywords: hijrah; Islam; e-commerce; opportunity; disruptive

\begin{abstract}
Abstrak: Tujuan dari penelitian ini adalah untuk menemukan sebuah strategi diruptif eCommerce Islam menggunakan model 5C (Commerce, Collaboration, Communication, Connection, and Computing). Metodologi yang kami gunakan adalah deskriptif kualitatif, untuk mengevaluasi dan menggambarkan aspek inovasi berdasarkan model 5C. Kami menawarkan sebuah pendekatan sistematik untuk mengenali strategi disruptif Nabi Muhammad dalam menggusur pasar besar milik petahana dan juga menyediakan strategi komersil dalam mengembangkan dan menerapkan perdagangan Islam secara elektronik (Islamic e-commerce). Hijrah adalah pendekatan distruptif terbaik yang pernah dibuktikan oleh Nabi Muhammad Saw dengan menutup pasar Bani Qainuqa. Nabi Muhammad Saw menjalankan model 4C yaitu perdagangan, kolaborasi, komunikasi, koneksi, dan hanya komputasi yang tidak dapat dilakukan. Hasil temuan-temuannya menunjukan bahwa pelanggan tidak hanya untuk 'berbelanja', tapi ada tujuan lain memahami kaidah Ilmu sebelum amal dalam berbelanja. Sedangkan penjual tidak sekedar 'berjualan' namun berhijrah dengan nilai yang lebih agung. Hal ini tidak hanya perihal penggunaan teknologi tapi juga sebagai strategi disruptif.
\end{abstract}

Kata Kunci: hijrah; Islam; e-commerce; opportunity; disruptif

Economica: Jurnal Ekonomi Islam - Volume 10, Nomor 1 (2019) 


\section{Introduction}

Hijrah (emigrate) is the journey of Prophet Muhammad (PBUH) with His friends and family from Mecca to Yathrib, later renamed by him by Medina (Al-Mubarkpuri 2015). Allah SWT said in the Quran Surah 4 words 100 "And whoever Hijrah (emigrates) in the way of Allah will find in the earth many reinstatements and an affluence" (Quran.com 2016). In business perspective, Hijrah is about compelling reason to change their way. But to be great, Moslem needs Allah to change it. Allah SWT said in the Quran Surah 13 words 11 "Indeed, Allah will not change the condition of a people until they change what is in themselves" (Quran.com 2016). So, for creating new opportunity, we can do the new things by the value of Hijrah. It will disrupt itself with the helping of Allah SWT.

Even there is no requirement to transform a modern Islamic economics (Kadar and Masum 2011). Todays of market was shift to be electronic commerce known by e-commerce. Muslim would be wondering if the new manifestation of business will be reliable starting with the Islamic law side of the point from claiming to see (Zainul, Osman, and Mazlan 2004). Then the future research on e-commerce in service is understanding on how to identify and reach the newest breed of customers (Govindarajulu et al. 2004). To do it, researcher should understand the phenomenon on doing business according to Islamic perspective that would emigrate (Hijrah) the intention of sellers and buyers and adhere to Islamic principles (Shah et al. 2004). Consequently, There are cushion concerns among Muslims regarding electronic transaction from technological (e-commerce) and Islamic Law perspectives which require Islamic scholars to examine (Abdulgani and Suhaimi 2014). The principles of Islamic e-commerce differentiation should be about profit and Falah (glory) maximization (Mohammad and Shahwan 2013). When commerce maximize the profit, than alms - like zakah, infaq, shadaqah and waqaf - made balance the unbalance commerce as the impact 
of Riba (interest) system and also reach the Falah (glory) (Shah et al. 2004);(Iqbal 2017);(OJK 2015).

When prophet Muhammad (PBUH) disrupted the Bani Qainuqa Market, He was balanced commerce with alms, where the market as a Waqf from him. He was set up two key elements before the development of Medina market with production and trade (Omer 2011). He also was prepared the Muslim traders to comply the law of Islam, because if Muslim didn't prepare knowledge than they can be plunged into misery of forbidden transaction (Al-Mubarkpuri 2015). Even it is the most hated place but traders/sellers are the best profession and Muslim to be ordered it. Friends said "Once the Prophet, was asked about the livelihoods of the most good. He replied, 'A man works with his hands and every purchase Mabrur."(bin Hanbal 2001);(Hajr 2003).

Today, In line with that, what consumer desire with the pace of technology, payment, and logistics are shopping at every time and everywhere (Bjørnland et al. 2015);(EY 2016);(EY 2017);(Riedl, Farag, and Korenkiewicz 2016). While The path purchase from commerce to ecommerce hasn't changed consumer experience stages (awareness, consideration, conversion, and evaluation) (KPMG 2017). The change is the journey itself that will alter the motive of selling and purchasing. Many research about Islamic ecommerce only discuss in the perspective of customers [(M. B. Ribadu and W. N. W. A. Rahman 2016a), (Abdulgani and Suhaimi 2014), (M. A. Suhaimi et al. 2013)], payment processing (Amboala et al. 2015), sharia compliance [(Ribadu and Rahman 2017), (Zainul, Osman, and Mazlan 2004), (Mokhtar et al. 2013), (M. Muhammad et al. 2013), (Ribadu and Wan Ab. Rahman 2017), (M. R. Muhammad, Muhammad, and Mohammed Khalil 2013)], aspect and challenges [(Amin 2008), (Shah et al. 2004), (Alotaibi and Asutay 2015)].

In this paper we will answer the desire of Moslem society about Islamic electronic transaction. The value of Hijrah have an new thing to build them as

Economica: Jurnal Ekonomi Islam - Volume 10, Nomor 1 (2019) 
the epicenter of disruption for making the new opportunity in Islamic eCommerce with the balancing of commerce and alms. It comes from the spirit of Quran in Surah 2 words 275-276 that in line with Surah 17 words 81. It means, If the truth has never built then falsehood will not be replaced. Incumbent today is falsehood that highly structured and systematic, so disruptive strategy will come from the value of Hijrah. We identify state of the art of value of Hijrah through 4 aspect that include commerce, collaboration, communication and connection (4C) and also complementary with computation as the strategy of commercializing Islamic e-Commerce.

\section{Literature Review}

\section{Islamic Economic Point of View}

The science of Islamic economic come up since the last period of prophet from the practice of Prophet Muhammad as an entrepreneur (Mohammad and Shahwan 2013). An economic system should achieve the objective of Islamic law in order to serve the responsibility as a leader of the earth and deserve the Falah (glory) (Su'ud 1994). Falah (glory) has been common objective of Islamic economic, it is not only vertical type of relationship but covers human activities to fulfillment a mercy to the worlds (Mohammad and Shahwan 2013);(Chapra 1992)(Khan 1995);(Chaudry 1999). A financial framework identifies to Islamic wealth management in a society that empowering or confining the wealth through utilizing the method of production through three main aspects: (1) Ownership of property, commodities and wealth. (2) Allocation of ownership. (3) Distribution of wealth among the people (Ayub 2007).

The basic principles of Islamic transaction (mu'āmalāt) are that the purpose of financing should devoid of Riba, Maysir, Gharar, unjust, Haram and the financing adhere with Islamic law of contract (Shanmugam and Zahari 2009). Capitalist system is treated money as a commodity besides being a medium of exchange and measure of value. Like other commodities, 
it has a price and the price means Riba or usury (Khan 1995). Riba or usury scientifically assigns value added that must be paid by the borrower for a loan or for an extra time of loan (Askari, Iqbal, and Mirakhor 2015).

Allah SWT was said in the Qur'an, there are two different concepts that can drive the economy, it divided two halal concepts with the sale and purchase and Shadaqah (alms) (Iqbal 2017). Allah SWT said in the Quran surah 2 words 275 "...Allah has permitted trade and has forbidden interest..." (Quran.com 2016). Allah also said in the Quran surah 2 words 276 about Shadaqah (alms) that will gives increase for charities or shadaqah (Quran.com 2016) (See figure 1).

The other concept is haram, it was as a big system in the world. It is known by interest or usury or Riba when it concept against with the others. Allah SWT said in the Quran about Riba surah 30 words 39 "And whatever you give for interest to increase the wealth of people will not increase with Allah. But what you give in zakah, desiring the countenance of Allah - those are the multipliers" (Quran.com 2016). Riba was embedded in the way of life of people include Muslim, whereas Allah SWT invites war against people who operate business with Riba. Allah SWT said in the Qur'an Surah 2 words 279 "And if you do not, then be informed of a war [against you] from Allah and His Messenger..." (Quran.com 2016).

As mention above, the worst and most hated place is market where commerce and e-commerce be placed. The very basic differentiation both is event of transaction, where commerce event is face to face known by offline (without network) while e-commerce using computer network known by online (Kutz 2016). We resume in the Quran and Hadith that there two big picture of commerce, first is commerce as a trade include Halal/permitted and blessed of commerce and second is commerce with Allah as a fertilized and doubled of commerce. 
Figure 1. Islamic Economy Concepts Islamic Commerce Perspective

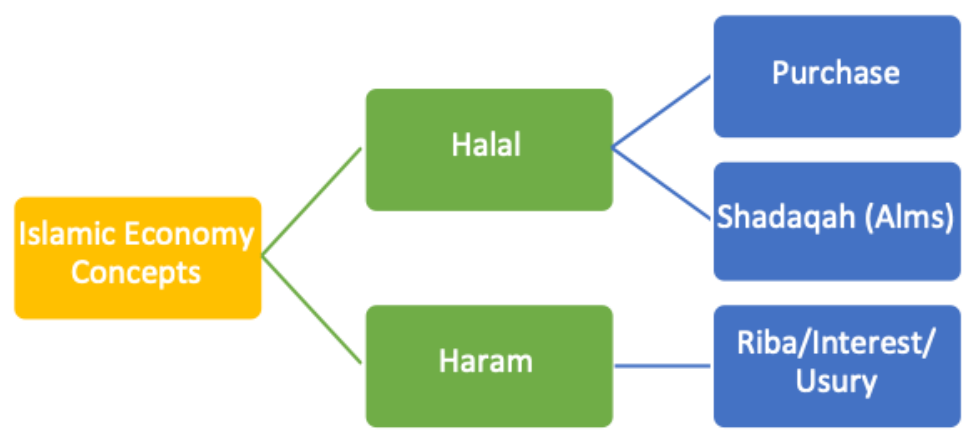

Quran said in the Surah 2 words 275 about permitted trade or commerce and blessed of commerce by hadith by Hakim bin Ibn Hizam (may Allah be pleased with him) reported that: Rasulullah (PBUH) said "both parties in a business transaction have a right to annul it so long as they have not separated; and if they tell the truth and make everything clear to each other (i.e., the seller and the buyer speak the truth, the seller with regard to what is purchased and the buyer with regard to the money) they will be blessed in their transaction, but if they conceal anything and lie, the blessing on their transaction will be eliminated (Muslim 2005);(Nawawi 2014).

Furthermore, Rasulullah (PBUH) said about fertilized commerce by Abu Huraira (Allah be pleased with him) reported "When a man dies, his acts come to an end, but three, repeating charity, or knowledge (by which people) benefit, or a pious son, who prays for him (for the Deceased)" (Muslim 2005);(Sunnah.com 2018c). The last is double margin of commerce when Allah said in the Quran surah 57 words 18 "Indeed, the men who practice charity and the women who practice charity and [they who] have loaned Allah a goodly loan - it will be doubled for them, and they will have a noble reward" and surah 64 words 17 "If you loan Allah a goodly loan, Allah will double it for you and forgive you. And Allah is Most Appreciative and Forbearing"(Quran.com 2016). 
In general, we classify that there are three types of commerce in the perspective of Islam. First is selling and buying activities in the market known by trading in the Quran surah An-Nisa words 29 "O you who have believed, do not consume one another's wealth unjustly but only [in lawful] business by mutual consent...".

Islam teaches about tijāratun not only about the amount of revenue gained in the market from a business activity exceeds the expenses, costs, and taxes needed to sustain the activity. Commerce or tijäratun in the perspective of Islam are two sides interrelated of relationship where the horizontal relationship (worldly commerce) between Traders or تاجر (tajir) and buyers will not release the hereafter commerce (vertical relationship) with Allah SWT. It is essential to know a thing first (Syariah law) before saying or acting (commerce) upon it (Sunnah.com 2018b).

The new thing of commerce that we are looking for is started at the mosque as the opposite of the market where commerce is placed. It is why Muslim Hijrah (emigrated) should know a thing first like Islamic law especially for a man. Because the high potentials unlawfulness of commerce will tend to do by a man. The Special requirement whom never neglected of commerce was written in the Quran surah An-Nur words 36-37. They are men (traders) whom always pray and giving Zakat and remembering ALLAH in the morning and evenings at the mosque. (Quran.com 2016).

The three types of factor that need to be managed carefully to create the new thing that can create the opportunity for disruption. It is resources, process, and values (Bower and Christensen 1995), (Christensen and Overdorf 2000), (Christensen, Johnson, and Rigby 2002), (Christensen, Raynor, and McDonald 2015). A man who means in the surah An-Nur 36-37 above is the main resources that can make the trembling of incumbent company to be displaced. But, Muslim traders should be careful from neglectful commerce and or distortion of Allah SWT. It is important to 
prepare the trader's man by design and on mission to set up the commerce who comply with Islamic law.

\section{Hijrah (Emigrate) Market (Open Business Model)}

After Hijrah (emigrate) from Mecca to Medina, Rasulullah (PBUH) was formerly developing Medina market because of economic control by Jew. That is the new things who Rasulullah (PBUH) believes that can create the opportunity in the future. Madina Market is as antithesis of Arabic Jewish (Bani Qainuqa) market to avoid Moslem for eating illegal things [as Bribes and Riba (usury), etc]. Allah SWT said in the Quran Surah 5 words 62 about The Jewish habits hastening into sin and aggression and the devouring of [what is] unlawful. If we See figure 1 above compare what Jew did it, Muslim should clear that in developing Islamic economy, they can't mix the truth or halal with something forbidden or haram but they also can't only doing commerce. It should be balance between commerce and alms. Allah SWT said in the Quran Surah 2 words 42 "And do not mix the truth with falsehood or conceal the truth while you know [it]".

Medina market was opened to disruption and try to displace the incumbent in order to facilitating Muslim - Hijrah - traders. It was transformed cemetery into small market where have given direct access to traders - product owner - that had been too expensive and too complex for the Jewish Market. It places of rendezvous and interact between customers and traders who dependent each other's is formerly known with Platform (Eisenmann, Parker, and Alstyne 2006). Rasulullah (PBUH) was succeeded in open-access platform and market entry.

Rasulullah (PBUH) was succeed to open new business model where the market performs two functions of disruption: (1) creates value, (2) captures value. He also was proven to offers lower performance and less functional at lower price that was typically disrupter performed. What value of Rasulullah (PBUH) have been created? Allah SWT said in the Quran Surah 3 words 110 
that means, Rasulullah (PBUH) was accompanied with the best trader even He has five follower as the richest Muslim as that time. If we compare the whole wealth of Abdurrahman bin Auf with Bill Gates, he was 6 times richer than the Bill Gates. But after Hijrah, he had left all his wealth back in Mecca and build a business start-up with nothing in Medina.

Abdurrahman bin Auf is one example of the series activities in Medina market when Rasulullah (PBUH) try create value that could enable a new set of customers to consider and made trading so simple and inexpensive. Media market was built as an endowment (Waqf) from Rasulullah, however After launching the market, Rasulullah (PBUH) said: "This is your market, it is not to be narrowed (by acquiring and building, for instance) and no tax is to be collected from it." (Al-Mubarkpuri 2015). Consequently, the Jewish market was priced to be expensive going through decreased of revenues and finally closed because all customer moved to the Media market. Medina market was successful in capturing value by establishing a unique resources (great traders), asset (endowment/Waqf), the series of activities and deserve a competitive advantage (Chesbrough 2006).

\section{Methods}

Some methodologies, framework, instruments, tools and decisionsupport system have been proposed to identify, build and forecast disruptive technology. The types are potential technology disruption (Christensen, Raynor, and McDonald 2015), (Bower and Christensen 1995) (Rigby 2015), identify and develop (Christensen, Johnson, and Rigby 2002), commercialize disruptive technologies (S. K. Kassicieh et al. 2002), road mapping disruptive technology (Walsh 2004), text mining literature (Kostoff, Boylan, and Simons 2004), multi-stage factor of decision-making (Rafii and Kampas 2002), framework (Kilkki et al. 2018) and also Hijrah propose by prophet Muhammad (PBUH).

Economica: Jurnal Ekonomi Islam - Volume 10, Nomor 1 (2019) 
This research is qualitative. The type of study is descriptive. To evaluate of aspect of innovational opportunities, we conducted several exploratory interviews with Islamic scholar who experts in jurisprudence (fiqh) of commerce transaction. The practitioners are adviser for different community such as Indonesian Muslim Entrepreneurs Community, Islamic Banker, exBanker (Entrepreneurs), Founder of TAWAF (Indonesian Waqf \& Ta'awun Foundation), Founder of Start-up Technology, founder of Indonesia commerce transaction (mu'ämalāt) school (Sekolah Muamalah Indonesia). Each of them was questioned about one of the potential of disruptions on electronic commerce. These interviews consisted in open and semi-open questions and took place between November 2017 and March 2018 and each lasted in two-eight hours.

To describe aspect of innovational opportunities, we identify aspect of ecommerce as propose by Vladimir Zwass, he proposed five main activity of ecommerce: commerce, collaboration, communication, connection and computation (5C model). After that, we evaluate aspect of the innovational opportunities based on 5C model (Zwass 2014).

\section{Results and Discussion}

\section{E-Commerce}

As mention above, the very basic understanding of e-commerce is even of transaction. E-commerce runs with the electronic network and the internet, involving a wide range of commercial transaction of seller and buyer in sale and purchase of goods and services (Rillo and dela Cruz 2016). The term E-commerce also includes activities throughout the value chain of the transaction process, and includes activities such as delivery of goods to locations favored by consumers (Competition Commision Singapore 2017).

While the basic proposed framework of Islamic e-commerce is categorized into two; Islamic law of contract, and Sharia prohibition in e- 
commerce (M. Muhammad et al. 2013);(M. B. Ribadu and W. N. W. A. Rahman 2016a). However the very important principles of commercial transaction at e-commerce will encompassing (1) offer and acceptance, (2) buyer and seller, (3) object and price (M. Muhammad et al. 2013);(M. B. Ribadu and W. N. W. A. Rahman 2016b);(M. R. Muhammad, Muhammad, and Mohammed Khalil 2013);(Ribadu and Rahman 2017). It is also include with the term of Khiyar (option), it refers to the authority given to buyer \& seller to rescind a contract of sale (Ribadu and Wan Ab. Rahman 2017). We are also include devoid of unjust in our framework as a prohibited transaction in ecommerce (Tarmizi 2013).

Today, both Muslim consumers and Muslim traders have had a movement that driven by awareness to adhere Islamic law and implemented in all of the models of business transaction (M. A. Suhaimi et al. 2013). It is what we call about "Hijrah Transaction" as a new market, when Muslim were not pay attention about their accumulate of wealth shift to studied about all of their transaction and make them comply to Islamic law. Why? Because Allah said in the Quran as the requirement of being a pious Muslim in the Surah 2 words 278 "O you who have believed, fear Allah and give up what remains [due to you] of interest/Riba, if you should be believers" (Quran.com 2016).

In order to facilitate Muslim to "hijrah transaction", we proposed seller verification framework as the requirements for Islamic purchase principles on Islamic e-commerce as a mention below (Figure 2). But if we compare in generic registry process at all e-commerce platform, we found there is no verification about sellers in order to understand what kind of sellers of them. It tends to unlawful of Islam if sellers (users platform) didn't verified yet, whether the sellers as (1) the agent of the owners of goods, (2) owner of goods and or (3) the producer (See figure 2). The verification process is very important to avoid one of the Hadith Rasulullah (PBUH) narrated by Hakim bin Hizam, " Hakim asked (the Prophet): Messenger of Allah, a man comes to 
me and wants me to sell him something which is not in my possession. Should I buy it for him from the market? He replied: Do not sell what you do not possess"(Sunnah.com 2018d).

But in the Medina market was easy to verified what kind of sellers of them, the problem will emerge when e-commerce platform owner can't see them. They didn't know whether they sell goods what they are owned or not yet. It is important devoid of gharar (uncertainty) and it is means there is uncertainty over the product whether it was bought by seller/trades or have not been handed over. Because if the seller was bought the goods doesn't necessarily recognized as the owner until handover. But it can be different between if the seller as the agent of the owner of goods, they recognized as the owner of goods as long as it has got a permission from the owner and also with the term and condition require. Prophet Muhammad (PBUH) said about agent in the hadith, Jabir bin Abdullah narrated, 'I intended to go to Khaibar, so I went to the Prophet Muhammad (to tell him) and he said to me, "If you meet my agent (who collects the Zakah property) at Khaibar, take fifteen Awsuq from him." (Hajr 2003).

Figure 2. Seller Verification Framework
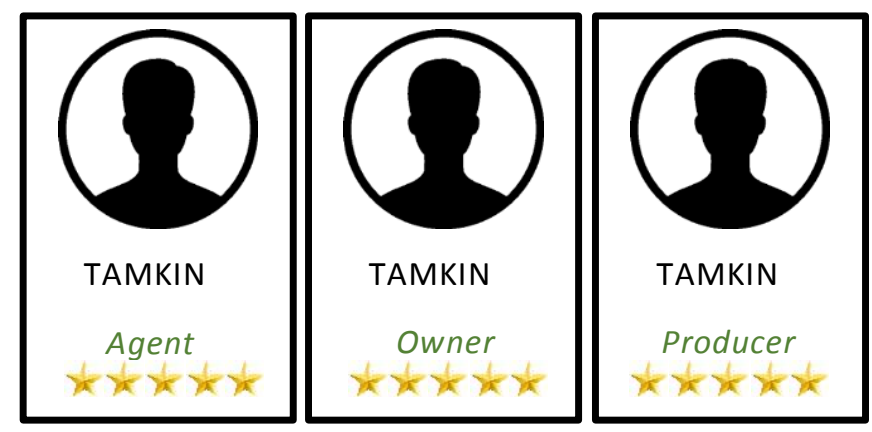
Hiijrah: Islamic E-Commerce Disurpted Strategy ...

\section{Collaboration}

The second domain activity of e-commerce is collaboration, it is means of building long-term relationship and increasing then over time, and as a platform, the Web can invites people to collaborate, interact, and learn on continuing innovation (Zwass 2014);(Liu and Brody 2016). Collaboration made an ecosystem that may create new opportunity and turning them into new product and services.

Collaboration not only reaching revenue growth and profit-making, it is combine with the need to respect and support its environment and stakeholder network (Kaji et al. 2018). Prophet Muhammad (PBUH) was displaced incumbent by given traders direct access to market that had been too unlawful of Islam for the mainstream (Bani Qainuqa market). He collaborate with his friends who expert in commerce to fight Riba/usury first. Jewish usually offers to all traders who need a capital with a model financing of Riba/usury and Allah said in the Quran about the habits of them in the Surah An-Nisa words 160-161 "For wrongdoing on the part of the Jews, We made unlawful for them [certain] good foods which had been lawful to them, and for their averting from the way of Allah many [people] (160), And [for] their taking of Riba/usury while they had been forbidden from it, and their consuming of the people's wealth unjustly. And we have prepared for the disbelievers among them a painful punishment (161) (Quran.com 2016).

In the words 161, Allah prohibited them from taking Riba', yet they did so using various kinds of tricks, ploy, and trickery, thus devouring people's property unjustly, whereas it is impossible for Muslim do a commercial transaction with Riba. Because Allah and His Prophet was announce and invite war to all people who include Riba/usury in their transaction. However after build a mosque, in order to against Riba/usury in Muslim community then Rasulullah (PBUH) build a unite in friendship between Muhajirin and Anshar (Muslim of Medina) (Al-Mubarkpuri 2015) and many

Economica: Jurnal Ekonomi Islam - Volume 10, Nomor 1 (2019) 
Muhajirin accepted to be adopted and some acceptance a loan to start business and which they pay back later (al Faruqi 1992). He was made an ecosystem collaboration between both and trying to enters a foothold market without Riba/usury.

He was also established line of production through land acquisition and said in the hadith narrated from Jabir bin Abdullah that the Prophet (PBUH) said: "Whoever revives a dead land, then it is for him" (Sunnah.com 2018a). Faith is what drives almost all His friends to acquire and replanting the land and many area of Medina transform into farming land. It is linear with the second means of Arabic vocabulary of the sequences of $ت$ and alphabet which is means production. We conclude that commerce in the concept of Islamic economy is the collaboration of product and service control between production as the upstream and commercial business as downstream. There will be no markets and commerce without production goods, therefore Rasulullah (PBUH) trying to adhere goods from Muslim producers and trying to weaken the Jewish domination.

Collaboration between traders and producers needs a platform to distribute the goods. The platform is a structure in which many product variations are create (Sampere 2016). Platform more broadly impact than product disruption, while product disruption only change what kind people buy and generate transient advantage whereas platform-based disruption create societal shifts in purchase (Sampere 2016);(KPMG 2017). Format of collaboration will create an activity based on Surah Al Baqarah 275-276 economy concept (Sale \& Purchase and alms (Waqf)). Each actor of collaboration has a different function where the producers creates the products while the seller will provide the products to the buyer at the ecommerce (See figure 3). 
Figure 3. Collaboration Framework

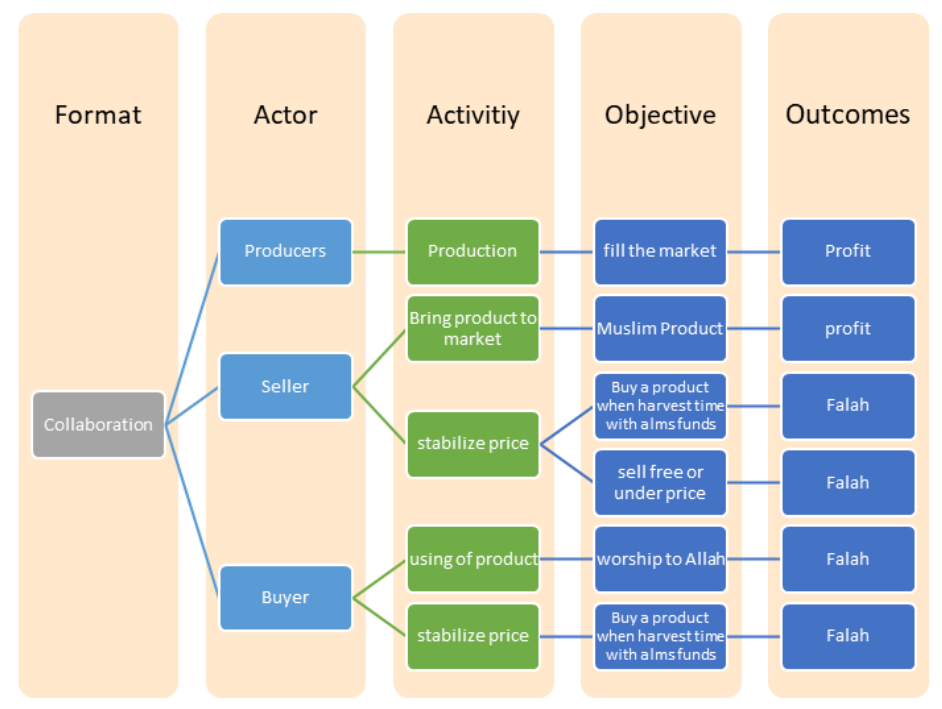

E-commerce platform not only result in more far-reaching societal shifts but it should be Hijrah intention of the seller/producers from revenue perspective to reach Falah (the glory) with the balancing of commerce and alms. If only talk about revenue streams, Muslim can't disrupt the big existing market, moreover Muslim also need to divert their alms not just pool of their funds to charities institution. Sometimes, Farmer need a capital to re-planting their fields and usually they receive a loan from moneylenders with charge of usury or riba. After they cropping grain, the price deceased result loss in two time (usury/riba and business loss). The diversion of Muslim alms (shadaqah) can prevent farmers from usury or riba and also it can stabilizing the price of grain when their shadaqah used to buy it in harvest time.

\section{Communication}

Today, the pace technology of messaging application emerge anti-riba communities in line with the growth of Islamic economy. They are the newest market of e-commerce market include people who convert to Islam,

Economica: Jurnal Ekonomi Islam - Volume 10, Nomor 1 (2019) 
Muslim entrepreneurs community, ex-bankers (Islamic and Conventional), many other anti-riba communities, Islamic economy student, alumni of school or workshop or training of commerce transaction, and etc. In 2016, the existing Muslim market was reached $11.9 \%$ of global expenditure or 2,000 billion dollars and was worth estimated 3,081 billion dollars in 2022 and is estimated to reach potential market size at 7.3\% CAGR through 2022 (Thomson Reuters 2017).

The platform is omnipresent and generally open, yet makes it conceivable to make private gathering spaces, or spaces with a coveted level of community and an arrangement of mechanical or standardizing principles of enrollment (Bell and Gemmell 2002). Prophet Muhammad (PBUH) was open communication with Muslim traders in order to ensure Syariah compliance were carried out (Kallek 1995). That the Messenger of Allah (PBUH) passed by a pile of food. He put his fingers in it and felt wetness. He said: 'O owner of the food! What is this ?' He replied: 'It was rained upon 0 Messenger of Allah.' He said: 'Why not put it on top of the food so the people can see it?' Then he said: 'Whoever cheats, he is not one of us.'" (Sunnah.com 2018a). Sometimes when Prophet Muhammad (PBUH) visit to the market and said about the habit of sellers about excessive and perjury words, therefore Prophet Muhammad (PBUH) to cleans up the transaction with shadaqah "O company of merchants, unprofitable speech and swearing takes place in business dealings, so mix it with sadaqah (alms)" (Sunnah.com 2018d).

Therefore, Islamic e-commerce should provide the line of communication when the contracting parties (buyer and seller) face up the problem that tends to unlawful of Islam. Today, Many Muslim Hijrah got a problem with their transaction and usually tends to breaking the law of Islam. In an attempt to secure the law of Islam and the existence of the market, the platform allow the authority for protects the value of Islam - in time of Umayyah Caliph was formerly known as Al-Hisbah institution - even 
The Rasulullah (PBUH) was rules as an Al-Hisbah himself. It was designed for running Islamic economic system as the highest supervision instrument of the market and their basic activities is invites to do good when the good is abandoned and prevents unjust in the hope of getting a reward in the hereafter (Kallek 1995).

The institution classified into three main function including the things relating the rights of Allah, the things relating the human rights, and also the things relating to common rights. In contemporary transaction related to Islamic e-commerce, the functions of Al-Hisbah as the highest level authority as a decision maker and can be classified into three main categories. The first category focus on Islamic law of contract, the pattern of communication embedded in platform of e-commerce where the contracting parties can ask for advice related to transactions that will be occur. The second category focus on sharia prohibition where the Muhtasib (al-Hisbah in charge) as the supervisor to approve or decline the product who sold by merchants. The third category is as a judge in case of dispute, it is means that in term of transaction the contracting parties should agree to pointed the Muhtasib as the judge in term of case of dispute of transaction.

\section{Connection}

Prophet Muhammad (PBUH) made a connectivity between two main line struggle and funding. He prepare his friends in the mosque before they move to the market. Therefore, no one who suddenly become a traders unless they ready as the Quran explain in the surah Al-Jumu'ah words 11 when they are not ready for commerce then they left the Prophet Muhammad "But when they saw a commerce or a diversion, [O Muhammad], they rushed to it and left you standing. Say, "What is with Allah is better than diversion and then a transaction, and Allah is the best of providers"' (Quran.com 2016).

Economica: Jurnal Ekonomi Islam - Volume 10, Nomor 1 (2019) http://journal.walisongo.ac.id/index.php/economica 
The first line of connection which is conducted by Prophet Muhammad (PBUH) when he arrive at Medina (after Hijrah) is connecting the mosque and the market. Mosque as the center of faith and the most beloved of places that was designed to his friends focus on build obedience and mentality. Because Allah said about requirements of traders or sellers is (1) a man, (2) commerce nor sale distracts from the remembrance of Allah (3) always pray in the morning and the evenings at the mosques (4) giving of Zakah, and (5) fear of hereafter (Quran.com 2016). Mosque not only as the place of pray and giving zakah but it is place of preparation - the second requirement - of a man who will come in the worst place namely market. Its connectivity result the funding for supplies the second line of connectivity (struggle).

When Prophet Muhammad (PBUH) was alive, Near from Medina Market or Manakhah Market (in time of Othoman Caliph), He take a seat to see Muslim traders at the market and see his friends who train horsemanship. It is an axis which is connected the funding and struggling (at Jabal Auhud) (See figure 4).

Figure 4. Connectivity Between Funding and Struggle

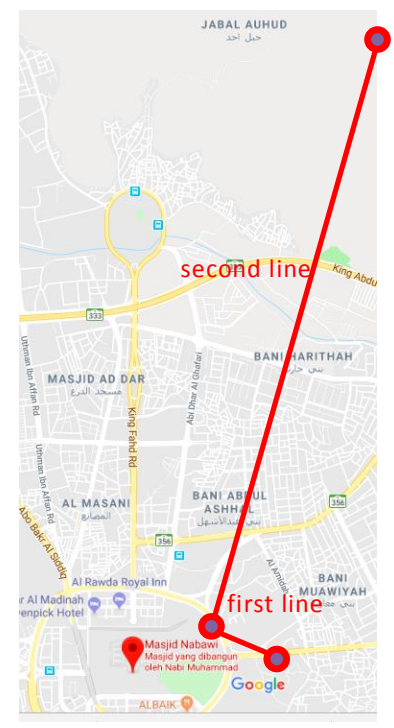


If we write a sequences of success, Mosque as the starting point, market as the second and the land of struggle as the latest. However Prophet Muhammad (PBUH) said in the hadith that struggle as the main practice of Islam "The head of the matter is Islam, its pillar is the prayer and its peak is jihad" (Badi 2016). Without successfully at Mosque, Muslim can't reach the successful in commerce or market and the last there is no supplies of wealth to support the land of struggle. Therefore Umar ibn Khattab said when Muslim troops are heading for war that "the differentiation between you and them is the obedience to Allah". It is comes up from the successful at Mosque and Market.

In addition the Prophet (PBUH) also connect two verses in the Qur'an (al-baqarah: 275-276) to counter the Riba or usury system. The first is sale and purchase with full of blessing where occur in the market that becomes the highest alms in Islam, it is Waqf or endowment. Sale and purchase and Waqf should find the equilibrium because only the harmonization both can defeat Riba or usury system (See figure 5).

Figure 5. Balanced Relationship Against Riba or Usury

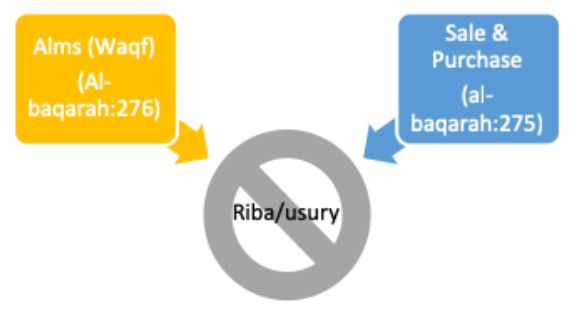

We have to develop a framework connectivity as built by Prophet Muhammad (PBUH) above as the connection strategy through Platform transaction. Islamic e-commerce have the form Waqf or endowment, it is the highest level of alms (shadaqah) because it allow the reward that keeps 
flowing from Allah. Before that, like a mosque which was developed Prophet friends an obedience, we have to implant an e-learning as the Transaction university to all traders before selling. As the axis, e-commerce also need funding to running the platform transaction (mu'āmalāt), therefore we also have to build an electronic alms in order to running it (See figure 6).

Figure 6. Core Concept of Platform Transaction (mu'āmalāt)

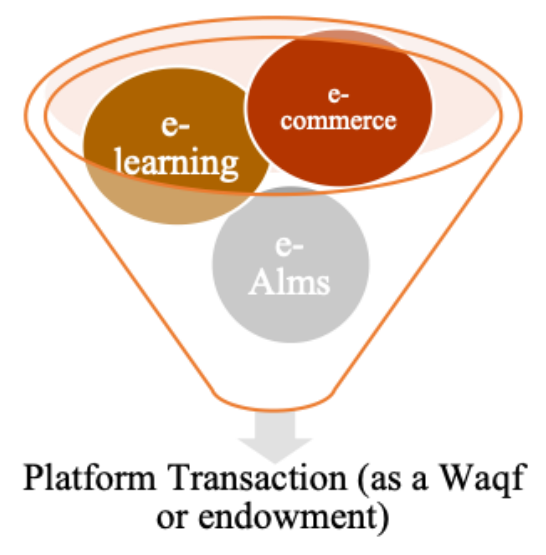

\section{Computation}

The first principles in developing of ecommerce platform in Islam is Waqf or endowment which is highly encouraged in Islam in developing Islamic civilization. The civilization of technology today dominated by capitalist to controlled all of start-up company who run in the field of electronic commerce.

The valuation of four unicorn from Indonesia leads by Go-Jek with was worth estimated USD 1 billion. It is include two from ecommerce sector which is Tokopedia and Bukalapak that is estimated IDR 28.3 Trillion. They have had pitch a fund from domestic and overseas investor. Moreover the 
very aggressive ecommerce in 2017 and prominently reach the position to two - Shopee - also owned by overseas company. Even top three shopping apps in southeast Asian markets dominated by capitalist (See figure 7) (Dailysocial.id 2017).

Figure 7. Top Three Shopping Apps

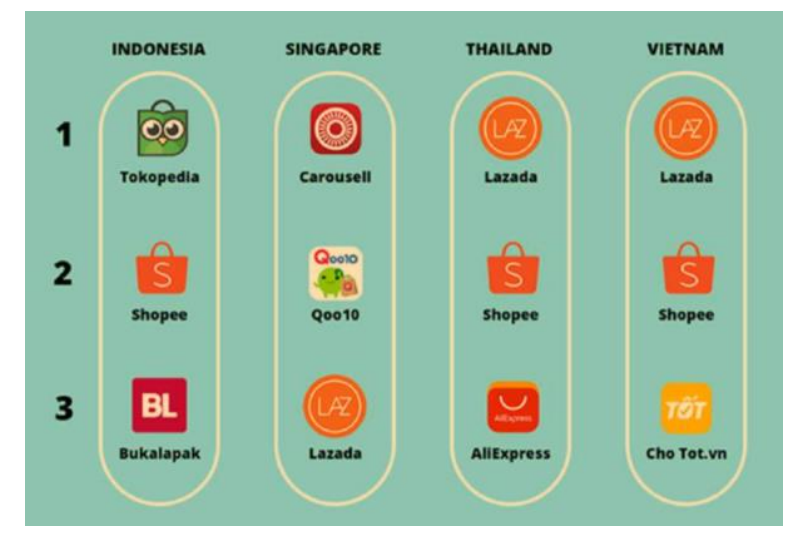

Indeed, the formation owned by waqf may avoid Islamic ecommerce controlling by company or people who do not understand of Islamic law. The computer program only owned by Allah and every founder who develop the platform get a reward that keeps flowing as long as it run well. It is also hold a maal or an asset - even intangible - and keeping up its consumption for the purpose of repeatedly harvesting its usufruct. It is also sunnah of Rasulullah (PBUH) as we mention above about waqf or endowment of Medina market from Him. The hadith narrated Kathir bin 'Abdullah bin 'Amr bin 'Awf AlMuzani, when Rasulullah (PBUH) said "Whoever revives a Sunnah of mine, which people then act upon, will have a reward equivalent to that of those who act upon it, without that detracting from their reward in the slightest" (Sunnah.com 2018e).

Therefore, it can disrupt by mercy (rahmat) and blessing (barakat) from Allah SWT. The Waqf platform will try to enliven Sunnah and hoping mercy from Allah as mention in the surah Al-Ahzab words 21 "There has certainly

Economica: Jurnal Ekonomi Islam - Volume 10, Nomor 1 (2019) 
been for you in the Messenger of Allah an excellent pattern for anyone whose hope is in Allah and the Last Day and [who] remembers Allah often" (Quran.com 2016).

It is also important to hope a blessing (barakat) from Allah because the blessed wealth is a wealth that brings goodness and grow up. Allah said in the Quran surah Al-A'raf words 96 about fear and faith are related with blessing (barakat) "And if only the people of the cities had believed and feared Allah, We would have opened upon them blessings from the heaven and the earth; but they denied [the messengers], so We seized them for what they were earning" (Quran.com 2016).

Platform Islamic ecommerce have two power from the faith of AlBaqarah 275-276. Muslim not only needs in developing platform of ecommerce to adhere Islamic law but providing the platform who blessing and merciful to disrupt the overcrowded ecommerce industries. Allah is also promising the glory to us as the authority of civilization of technology.

\section{Conclusion}

Value of Hijrah was closing the incumbent market with the beauty of Islamic law include two strategies which is the faith in the promise of Allah to Muslim traders and market belongs to Allah as a Waqf or endowment from the founder. The Islamic commerce can combine both as a disrupted strategies in order to provide to Muslim traders a platform Hijrah in transaction (mu'ämalāt) where Allah will set the beauty of incumbent displacement.

The problem about how to disseminate Islamic economy concept from Surah Al-Baqarah words 275-276 has been answered through combine between trading and waqf as a one package of business. E-Commerce platform as a place for seller and buyer to is only one concept of Surah 2 words 275. It is also require an ecommerce platform as waqf goods to disseminate the concepts of surah 2 words 276. 
The limitation of this research is about disrupted technological approach to implement the result. It is only explore about how to start up an ecommerce based on Islamic values. It is also need to use a decision-making methodology to utilize the collective wisdom of the organization to determine how likely it is those specific innovations will move through all of these stages and severely damage the incumbent business.

\section{References}

Abdulgani, Montadzah Ambag, and Mohd Adam Suhaimi. 2014. "Exploring Factors That Influence Muslim Intention to Purchase Online." 2014 the 5th International Conference on Information and Communication Technology for the Muslim World, ICT4M 2014, no. January. https://doi.org/10.1109/ICT4M.2014.7020637.

Al-Bisti, Ibnu Hibban. 1993. Shahih Ibnu Hibban. Vol. Juz 15. Beirut: Muassasah ar-risalah.

Al-Mubarkpuri, Sheikh SafiurRahman. 2015. Ar-Raheeq Al-Makhtum (The Sealed Nectar): Biography of the Prophet Muhammad. Houston: Simply Islam.

Al-Munziri, Al-Hafidz. 2010. Mukhtasor Sunan Abu Daud. Juz 3. Riyadh.

Alotaibi, Mohammed Naif, and Mehmed Asutay. 2015. "Islamic Banking and Islamic E-Commerce: Principles and Realities." International Journal of Economics, Commerce and Management III (4).

Amboala, Tamrin, Ainur Hafizah Anuar Mokhtar, Mohd Zulkifli Muhammad, Muhamad Fauzan bin Noordin, and Roslina Othman. 2015. "Development Method for Shariah Compliant E-Commerce Payment Processing." International Journal of Computer Theory and Engineering, Oct, 7 (5): 408-15. https://doi.org/10.7763/IJCTE.2015.V7.995.

Amin, Hanudin. 2008. "E-Business from Islamic Perspectives: Prospects and Challenges." Journal of Internet Banking and Commerce 13 (03).

Askari, Hossein, Zamir Iqbal, and Abbas Mirakhor. 2015. Introduction to Islamic Economics Theory and Application. 1st ed. Toronto: John Wiley \& Sons.

Economica: Jurnal Ekonomi Islam - Volume 10, Nomor 1 (2019) 
Ayub, Muhammad. 2007. Understanding Islamic Finance. Understanding Islamic Finance. 1st ed. Chichester: John Wiley \& Sons Ltd. https://doi.org/10.1016/j.pacfin.2013.09.002.

Badi, Jamal Ahmed. 2016. Commentary of Forty Hadiths of An Nawawi. Islamic Learning Foundation.

Bell, Chester, and Jim Gemmell. 2002. A Call for the Home Media Network. Vol. 45. https://doi.org/10.1145/514236.514237.

Bjørnland, Dag Frederik, Cyrus Ditzel, Pedro Esquivias, Jody Visser, Steve Knox, and Victor Sánchez-Rodríguez. 2015. "What Really Shapes the Customer Experience." Boston Consulting Group. https://www.bcgperspectives.com/Images/BCG-What-Really-ShapesCustomer-Experience-Sep-2015_tcm80-195636.pdf.

Bower, J L, and C M Christensen. 1995. "Disruptive Technologies: Catching the Wave." Harvard Business Review 73 (1): 43-53. https://doi.org/10.1016/0024-6301(95)91075-1.

Chapra, M. Umar. 1992. Islam and The Economic System. Vol. 2. 1.

Chaudry, M.A. 1999. "Fundamentals of Islamic Economic System." presented at the Burhan Education and Welfare Trust Lahore.

Chesbrough, Henry. 2006. Open Business Models. Boston: Harvard Business School Press.

Christensen, Clayton M, Mark W Johnson, and Darrell K Rigby. 2002. "Foundations for Growth: How To Identify and Build Disruptive New Businesses." MIT Sloan Management Review 43 (3): 22-31.

Christensen, Clayton M, and Michael Overdorf. 2000. "Meeting the Challenge of Disruptive Change Meeting the Challenge of Disruptive Change." Harvard Business Review, 12.

Christensen, Clayton M, M Raynor, and R. McDonald. 2015. "What Is Disruptive Innovation?" Harvard Business Review, no. December. https://hbr.org/2015/12/what-is-disruptive-innovation.

Competition Commision Singapore. 2017. "Handbook on E-Commerce and Competition in ASEAN." Competition Commision Singapore. https://www.ccs.gov.sg/media-and-publications/publications/inhouse-publications/asean-ecommerce-handbook.

Dailysocial.id. 2017. “Startup Report.” Jakarta: Dailysocial. 
Eisenmann, Thomas R., Geoffrey G. Parker, and Marshall W. Van Alstyne. 2006. "Strategies for Two-Sided Markets." Harvard Business Review 86 (10): 92.

EY. 2016. "World Islamic Banking Competitiveness Report 2016." Ernst \& Young Global Limited. http://www.ey.com/Publication/vwLUAssets/ey-world-islamicbanking-competitiveness-report-2016/\$FILE/ey-world-islamicbanking-competitiveness-report-2016.pdf.

—_- 2017. "The Future of Money." Ernst \& Young Global Limited. http://www.oecd.org/dataoecd/40/31/35391062.pdf.

Faris, Ibnu. 1979. Maqayis Al-Lughoh. Vol. Juz 1, Page 341. Beirut: Darul Fikr.

Faruqi, Ismail Raji al. 1992. Al Tawhid: Its Implication For Thought and Life. Second. Virginia: The International Institute of Islamic Thought.

Govindarajulu, Nalini, Shalini Devi, Yiling Ge, Maria Gonzalez, David T. Loyed, and Bonnie Daily. 2004. "Towards Theory Building in E-Commerce: Identification of Pertinent Research Streams and a Call for Further Research." In World Conference on POM, 2:1-17. Cancun.

Hajr, Imam ibn. 2003. Bulugh Al-Maram Min Adillat Al-Hakam. Edited by Selma Cook. El-Mansoura: Dar Al-Manarah.

Ḥanbal, Abû 'Abdillâh Muḥammad bin Aḥmad bin. 2001. Al-Musnad. Beirut: Mu'assasah Ar-Risâlah.

Iqbal, Muhaimin. 2017. Beyond The Horizon. 1st editio. Bogor.

Kadar, Abdul, and Muhammad Masum. 2011. "Mobile Commerce and Mobile Payment: A Study on Islamic Perspective" 2010 (December 2010): 3748.

Kaji, Junko, Karen Edelman, Abrar Khan, Nikita Garia, Matthew Budman, Rithu Thomas, and Preetha Devan. 2018. "The Rise of The Social Enterprise." Insights. Deloitte.

Kallek, Cengiz. 1995. "Socio-Politico-Economic Sovereignty and The Market of Medina." Journal of Islamic Economics 4 (1 \& 2): 1-14.

Khan, Muhammad Akram. 1995. An Introduction of Islamic Economics. 1st ed. Islamabad: International Institute of Islamic Thought.

Kilkki, Kalevi, Martti Mäntylä, Kimmo Karhu, Heikki Hämmäinen, and Heikki Ailisto. 2018. "A Disruption Framework." Technological Forecasting and

Economica: Jurnal Ekonomi Islam - Volume 10, Nomor 1 (2019) 
Social Change 129: 275-84. https://doi.org/10.1016/j.techfore.2017.09.034.

Kostoff, Ronald N., Robert Boylan, and Gene R. Simons. 2004. "Disruptive Technology Roadmaps." Technological Forecasting and Social Change 71 (1): 141-59. https://doi.org/10.1016/S0040-1625(03)00048-9.

KPMG. 2017. "The Truth about Online Consumers.” Swiss.

Kutz, Martin. 2016. Introducing to E-Commerce. 1st ed. bookboon.

Liu, Jeff, and Paul Brody. 2016. "Is Collaboration The New Innovation?" A N A LY T I C S E RV I C E S. Harvard Business Review \& EY.

M. A. Suhaimi, M. J. Mohamed Razi, H. Hussin, M. R. Muhammad, M. Muhammad, and K. Abdullah. 2013. "Conceptualizing Trust-Based Online Behavior Model for Muslim Consumers." In 2013 5th International Conference on Information and Communication Technology for the Muslim World (ICT4M), 1-6. https://doi.org/10.1109/ICT4M.2013.6518905.

M. B. Ribadu, and W. N. W. A. Rahman. 2016a. "A Generic Framework for ECommerce Requirements to Comply with Sharia in Business-toConsumer Perspective." In 2016 SAI Computing Conference (SAI), 75257. https://doi.org/10.1109/SAI.2016.7556064.

- _ . 2016b. "A Generic Framework for E-Commerce Requirements to Comply with Sharia in Business-to-Consumer Perspective." In 2016 SAI Computing Conference (SAI), 752-57. https://doi.org/10.1109/SAI.2016.7556064.

Mohammad, Mustafa Omar, and Syahidawati Shahwan. 2013. "The Objective of Islamic Economic and Islamic Banking in Light of Maqasid Al-Shariah: A Critical Review." Middle-East Journal of Scientific Research 13: 75-84. https://doi.org/10.5829/idosi.mejsr.2013.13.1885.

Mokhtar, Ainur Hafizah Anuar, Tamrin Amboala, Mohd Zulkifli Muhammad, and Mohd Sarwar E-alam. 2013. "Bai As-Salam And E-Commerce: A Comparative Analysis From Sharia Perspectives." In Proceedings of the 2nd Applied International Business Conference (AIBC2013). Vol. 2nd. Sabah: Universiti Malaysia Sabah.

Muhammad, Marjan, and Muhd Rosydi Muhammad. 2013. "Building Trust in E-Commerce: A Proposed Shari'ah Compliant Model." Journal of Internet Banking and Commerce 18. 
Muhammad, Marjan, rosydi Muhammad Muhd, Mohd Adam Suhaimi, Mohamed Jalaldeen Mohamed Razi, and Kalthom Abdullah. 2013. "Building Trust in E-Commerce from an Islamic Perspective: A Literature Review." American Academic \& Scholarly Research Journal 5 (5): 161-68.

Muhammad, Muhd Rosydi, Marjan Muhammad, and Khalil Mohammed Khalil. 2013. Towards Shari'ah Compliant E-Commerce Transactions: A Review of Amazon.Com. Vol. 15. https://doi.org/10.5829/idosi.mejsr.2013.15.9.11176.

Muslim, Imam. 2005. Shahih Muslim. Edited by Muhammad Mahdi Al Sharif. 1st ed. Cairo: Dar Al kotob \& Jarir Bookstore.

Nawawi, I. 2014. Riyad As Salihin: The Gardens of the Righteous. Tughra Books. https://books.google.co.id/books?id=CxhRCwAAQBAJ.

OJK. 2015. "Roadmap Perbankan Syariah Indonesia 2015-2019." Jakarta: Otoritas Jasa Keuangan.

Omer, Spahic. 2011. Madinah Market During The Prophet's TIme (Part 2). https://medinanet.org/2011/03/madinah-market-during-theprophets-time-part-2/.

Ondrus, Jan, and Yves Pigneur. 2005. "A Disruption Analysis in the Mobile Payment Market." System Sciences, 2005. HICSS'05. Proceedings of the 38th Annual Hawaii International Conference On 00 (C): (pp. 84c-84c). IEEE. https://doi.org/10.1109/HICSS.2005.9.

Quran.com. 2016. Noble Quran. https://quran.com/.

Rafii, Farshad, and Paul J. Kampas. 2002. "How to Identify Your Enemies before They Destroy You." Harvard Business Review 80 (11): 115.

Ribadu, Mohammed Bashir, and Wan Nurhayati Wan Ab Rahman. 2017. "An Integrated Approach towards Sharia Compliance E-Commerce Trust." Applied Computing and Informatics. https://doi.org/10.1016/j.aci.2017.09.002.

Ribadu, Mohammed Bashir, and Wan Nurhayati Wan Ab. Rahman. 2017. "Sharia Compliance Service Quality Metrics For E-Commerce: An Exploratory Analysis." Proceedings of International Conference on Computing and Informatics 6th (April): 332-40.

Economica: Jurnal Ekonomi Islam - Volume 10, Nomor 1 (2019) 
Riedl, Jens, Hady Farag, and Dorota Korenkiewicz. 2016. "Transportation and Logistics in a Changing World." Boston: Boston Consulting Group.

Rigby, Darrell K. 2015. Management Tools 2015. Boston: Bain \& Company, Inc.

Rillo, Aladdin D, and Valdimir dela Cruz. 2016. "The Development Dimension of E-Commerce in Asia: Opportunities and Challenges." Papers and Brief 2016-2. ADBI Policy Brief. Japan, China, People's Republic of, United States, Switzerland, India: Asian Development Bank. https://www.adb.org/publications/development-dimension-ecommerce-asia-opportunities-and-challenges.

S. K. Kassicieh, S. T. Walsh, J. C. Cummings, P. J. McWhorter, A. D. Romig, and W. D. Williams. 2002. "Factors Differentiating the Commercialization of Disruptive and Sustaining Technologies." IEEE Transactions on Engineering Management $49 \quad$ (4): 375-87. https://doi.org/10.1109/TEM.2002.807293.

Sampere, Juan PabloVazquez. 2016. "Why Platform Disruption Is So Much Bigger than Product." H02STS. Harvard: Harvard Business Review.

Shah, Nuradli Ridzwan, Mohd Zainal Munshid, Faizah Bte Mohd Khalid, and Hanifah Bte Abdul Hamid. 2004. "E-Commerce In Islamic Perspectives: The Theoretical Framework, Key Success Factor And Challenges For Islamic E-Commerce Business." In Proceeding of Knowledge Management International Conference. Malaysia.

Shanmugam, Bala, and Zaha Rina Zahari. 2009. A Primer On Islamic Finance. Edited by Elizabeth Collins. Salient. 1st ed. The Research Foundation of CFA Institute and the Research Foundation. https://doi.org/10.4103/0974-2700.76845.

Sunnah.com. 2018a.Jami At-Tirmidhi. sunnah.com.

___. 2018b. Sahih Al-Bukhari. Book 3, Hadith 10. sunnah.com.

_—_. 2018c. Sahih Muslim. sunnah.com.

-_— 2018d. Sunan Abi Dawud. Book of Wages. sunnah.com.

_-_ 2018e. Sunan Ib Majah. The Chapters on Business Transactions. sunnah.com.

Su'ud, M.A. 1994. Outlines of Islamic Economics. Kuwait: International Islamic Book Centre. 
Suzuki, Yasushi. 2013. "A Post-Keynesian Perspective on Islamic Prohibition of Gharar." International Journal of Islamic and Middle Eastern Finance and Management 6 (3): 200-210.

Tarmizi, Erwandi. 2013. Haram Wealth in Contemporary Muamalah. 5th ed. Bogor: Berkat Mulia Insani.

Thomson Reuters. 2017. "State of The Global Islamic Economy: 2017-2018 Report." Dubai: Dubai The Capital of Islamic Economy.

Walsh, Steven T. 2004. "Roadmapping a Disruptive Technology: A Case Study: The Emerging Microsystems and Top-down Nanosystems Industry." Roadmapping: From Sustainable to Disruptive Technologies 71 (1): 161-85. https://doi.org/10.1016/j.techfore.2003.10.003.

Zainul, Norazlina, Fauziah Osman, and Siti Hartini Mazlan. 2004. "ECommerce from an Islamic Perspective." Electronic Commerce Research $\begin{array}{llll}\text { and } \quad \text { Applications } & 3 & \text { (3): } & \text { 280-93. }\end{array}$ https://doi.org/10.1016/j.elerap.2004.01.002.

Zwass, Vladimir. 2013. "The Framework and The Big Ideas of E-Business." In Handbook of Strategic E-Business Manajemen, 3-14. Part 1. New York: Springer.

2014. "Electronic Commerce and Organizational Innovation: Aspects and Opportunities." International Journal of Electronic Commerce 7 (3): 7-37. 
